\title{
SPONSORSHIP CONGRUITY AND ATTITUDE TOWARDS ADVERTISING IN MUSIC FESTIVALS: THE ROLE OF TRUST AND SOCIAL MEDIA ENGAGEMENT
}

\author{
Pedro Manuel do Espírito Santo ${ }^{1}$ and Sara Santos ${ }^{2}$ \\ ${ }^{I}$ Instituto Politécnico de Coimbra, ESTGOH, Rua Gen. Santos Costa, 3400-124 Oliveira do Hospital \\ ${ }^{2}$ Escola Superior de Educação de Coimbra, R. Dom João III, 3030-329 Coimbra
}

\begin{abstract}
The number of festivals is increasing all over the world. Most people search for living moments and experiences that will retain in their mind and shared in social media. At the same time, social media change daily habits of people, special younger ones.

In this study, in the context of music festivals, it is analyzed the relation among trust, attitude toward "new" advertising, and congruence between the sponsoring brand and the event as influencing factors in social media engagement.

Results show that trust in the sponsoring brand of an event is explained by the congruence between the sponsoring brand and the event and by the attitude of individuals to creative brand advertising. On the other side, in social media engagement, consumption is influenced by congruence, by the attitude of individuals to advertising and by trust.

These results show that sponsorship congruity and attitude toward advertising have effects on consumption and trust. Thus, brands should look with special attention to the events before they sponsor them.
\end{abstract}

\section{KEYWORDS}

Sponsorship Congruity, Attitude Towards Advertising, Brand Trust, Social Media Engagement, Festivals

\section{INTRODUCTION}

Brands increasingly seek to build lasting relationships with their customers. Being present and sponsoring festivals has been a recurring strategy primarily to create closeness special to younger generations. Festivals are not only important to build relations and interactions with sponsors, brands, attendees and the community (Gursoy, Kim, \& Uysal, 2004) but also to provide involvement with the cultural and social environment (Rowley \& Williams, 2008). According to Crompton \& McKay (1997, p. 429) "a festival implies that visitors are likely to be seeking cultural enrichment, education, novelty, and socialization". For these authors there are four motives to attend a music festival: (1) cultural exploration, in other words, people want to experience different cultural activities; (2) novelty/regression, to live different experiences; (3) recover equilibrium, to escape from daily routine; (4) external interaction/socialization, to meet and to amuse with different people; (5) known-group socialization, spending quality and amazing time with friends; and (6) family togetherness, improving family relationships. For these reasons, brands used sponsorship strategies to get closer to its public and achieve marketing objectives.

On the other side, social media could help brands to build long-term relationships with attendees of festivals that share information with each other as well as non-attendees (Hudson, Roth, Madden, \& Hudson, 2015). However, authors emphasize that this relation between social networks sites brands and festival attendees needs further investigation (Hudson et al., 2015).

In this study we search to deepener this investigation, analyzing trust, attitude toward "new" advertising, and congruence between the sponsoring brand and the event as influencing factors in social media engagement (namely in consumption and contribution). As little is known about how sponsorship of festivals drives engagement with brands on social media, we propose to contribute with theorical and practical results. 


\section{LITERATURE REVIEW}

\subsection{Sponsorship Congruity with the Event}

Brands search to improve their image and perception through good memories in the consumer's mind through stimuli that strengthen brand associations. Therefore, there are several brands that seek a greater repeated exposure to potential consumers so that this stimulus increases the likelihood of relation with the brand and leads to an affective reaction to the brand (Woisetschläger \& Michaelis, 2012).

Events are important assets for the growth of visitor flows to a region or city, improving the competitiveness of destinations and promoting the creation of local jobs and income. Nowadays, the financial viability of many regional festivals and events depends to a large extent on brand sponsorship (Shin, Lee, \& Perdue, 2018).

Brand sponsorships allow to increase the exposure of these brands to an audience that might not otherwise have any contact with the brand. Sponsorship is summarized in the work of Chebli and Gharbi (2014) which describe the sponsorship of a brand to an event as an investment (financial or through the transfer of materials), about an activity, person or event and has access to a possible communication associated with that activity, person or event. However, event sponsorship literature has studied congruence theory as a theoretical tool for analysing whether the image of a sponsoring brand is consistent with the image of the event. This research focused mainly on the congruence between the visitor's self-image and the image of the event and the congruence between the sponsorship of the brand image and the image of the event (figure 1) (Shin et al., 2018).

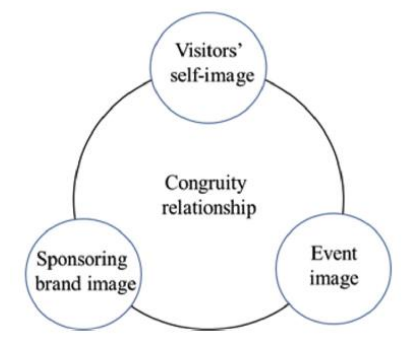

Figure 1. Congruity Relationship Source: Shin et al. (2018)

Shin et al. (2018) refers that the exposure of individuals to a brand improves their involvement and the relationship that each individual has with the brand. Self-congruence with the sponsorship event helps to create a favourable attitude towards this event, and these positive feelings overflow to the company (Sirgy, Lee, Johar, \& Tidwell, 2008). Engagement with brands improves when the congruence between the sponsored event and the brand is high, causing change in attitudes (Woisetschläger \& Michaelis, 2012). It is no wonder that when individuals are involved with the event, they are more likely to spend more time and energy on the event and the positive feelings they have about the event are more likely to be transferred to the sponsored brands than when individuals are not highly involved (Sirgy et al., 2008).

Thus, this study intends to test the following hypotheses of investigation:

H1: The congruence between the event and the brand has positive effects on brand trust.

$\mathrm{H} 2$ : The congruence between the event and the brand has influence in the engagement with the brand in the social networks.

\subsection{Attitude towards Advertising (Novelty)}

Creativity in advertising is essential to the effectiveness of advertising. Creativity has long been recognized as one of the most important concepts in designing and developing effective advertising (Baack, Wilson, van Dessel, \& Patti, 2016).

Consumer responses may be affective, behavioural or cognitive (Pochun, Brennan, \& Parker, 2018) and create systems of meanings and associations between the intended message and life experiences that trigger experiences and different emotions. As ad clutter exists, ad creativeness is even more important in generating 
attention and fostering trust. The attitude of each individual to innovative advertising promotes greater levels of brand's trust (Varki \& Ashley, 2011). Thus, this study seeks to evaluate the following research hypothesis:

H3: The attitude to advertising (Novelty) has positive effects on brand trust.

Nowadays, the new communication formats are based on customized communication models that use social media/networks and events in an integrated way (de Waal Malefyt, 2015). Thus, the following hypothesis of investigation is formulated:

H4: The attitude to advertising (novelty) has positive effects on the consumption of content in social networks.

\subsection{Brand Trust}

Brand Trust is a concept widely study in marketing literature, mostly associated with brand loyalty. Lau \& Lee (1999, p. 344) define brand trust as "a consumer's willingness to rely on the brand in the face of risk because of expectations that the brand will cause positive outcomes". In situations of information asymmetry, fear of opportunism or uncertainty, trust has the role of decrease this this doubts and make customers feel comfortable with the brand (Cheung, Chiu, \& Lee, 2011). Therefore, brand trust is related with building strong relationship and brand loyalty. According with several authors (Cheung et al., 2011), trust is one of the main antecedents of loyalty. Burmann, Jost-Benz, \& Riley (2009, p. 391) emphasize that brand trust represents "the basis for long-term customer relationship".

In online communities, brand trust has a mediating role in converting the effects of enhanced relationships in brand community to brand loyalty.

\subsection{Social Media/Networks Engagement}

Social media has changed the way people interact with brands as well as other people. Xiang \& Gretzel (2010) define social media as internet-based applications that encompass media impressions created by consumers, resulted from experiences and archived or shared online and that could be accessed by other people. However, other authors evidence that not only for socialization but also entertainment, rewards, search information (Muntinga, Moorman, \& Smit, 2011), among others.

Muntinga et al., (2011) proposed a Consumer Online Brand-Related Activity (COBRA) model which distinguishes consumer engagement on social media in three types of behavior: consumption (when consumers view images and videos, read information, comments and reviews), contribution (when users like or comment photographs and videos and engage in conversations about the brand); creation - users produce and publish content related to the brand (Muntinga et al., 2011). However, when applied to social network sites, Tsai \& Men (2013) used the Muntinga et al. (2011) typology only with the variables "consumption" and "contribution". The study of Hudson, Huang, Roth, \& Madden (2016) concluded that consumers who engage with their favorite brands using social media have stronger relationships with those brands compared with consumers who do not interact. Thus, the fifth hypothesis is:

H5: Brand trust has positive effects on the consumption of content in social networks.

Based on the COBRA model (Muntinga et al., 2011), Schivinski et al. (2016) consider that there is a hierarchical relationship between the three dimensions of engagement: consumption, contribution and creation. This study intends also to analyze whether the same hierarchical relationship (consumption-contribution) occurs in the engagement of the festivalgoers. Thus, the last hypothesis is:

H6: Consumption of content in social networks has influence on contribution.

This formulation of hypothesis resulted in the conceptual model formulated in figure 2. 


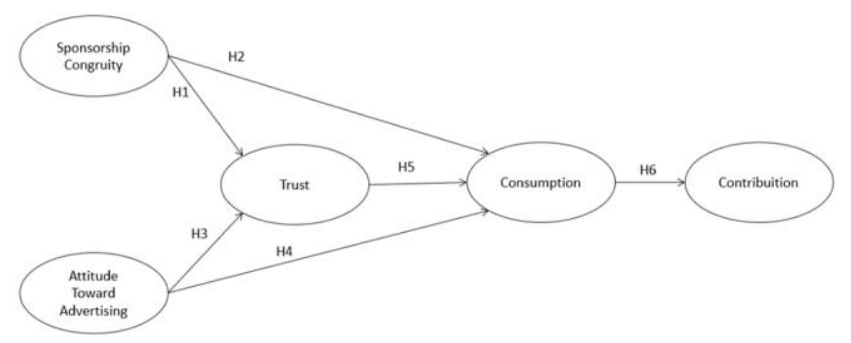

Figure 2. Conceptual Model

\section{METHODOLOGY}

The present study of a conclusive-causal nature had simple transversal characteristics whose unit of analysis were individuals who already had some experience in music festivals and who identified the sponsoring brands of the last festival in which they participated. The concepts under study were operationalized through 5-point Likert scales, tested in the literature, and whose original studies of which were adapted are described in table 1.

Table 1. Constructs, Items and References

\begin{tabular}{|c|c|c|c|c|c|}
\hline Constructs & Items & Mean & $\begin{array}{l}\text { Std } \\
\text { Dev. }\end{array}$ & $\lambda$ & Code \\
\hline \multirow{5}{*}{$\begin{array}{l}\text { Attitude } \\
\text { towards } \\
\text { advertising } \\
\text { (ATT) } \\
\text { (Varki and } \\
\text { Ashley, 2011) }\end{array}$} & Event sponsor ads are original. & 3,54 & 0,91 & $0,835 * *$ & ATT01 \\
\hline & Ads from the event sponsor are memorable. & 3,26 & 0,99 & $0,822 * *$ & ATT02 \\
\hline & I'm interested in the sponsorship ads of the event. & 3,29 & 1,06 & $0,869 * *$ & ATT03 \\
\hline & Ads from the event sponsor are interesting. & 3,43 & 0,96 & $0,919 * *$ & ATT04 \\
\hline & $\begin{array}{l}\text { There is something different about sponsor advertising } \\
\text { for the event. }\end{array}$ & 3,17 & 0,99 & $0,874 * *$ & ATT05 \\
\hline \multirow{6}{*}{$\begin{array}{l}\text { Sponsorship } \\
\text { Congruity } \\
\text { (CONG) } \\
\text { (Koo and Lee, } \\
2018)\end{array}$} & $\begin{array}{l}\text { The advertising of brand sponsorship of the event is } \\
\text { consistent with my way of being. }\end{array}$ & 2,97 & 0,97 & $0,685 * *$ & CONG01 \\
\hline & $\begin{array}{l}\text { The advertising of brand sponsorship of the event is } \\
\text { consistent with how others see me. }\end{array}$ & 2,81 & 1,01 & $0,653 * *$ & CONG02 \\
\hline & $\begin{array}{l}\text { There is a logical connection between the music festival } \\
\text { and its main sponsor. }\end{array}$ & 3,56 & 1,06 & $0,806 * *$ & CONG03 \\
\hline & $\begin{array}{l}\text { The image of the event and the brand image of the main } \\
\text { sponsor are similar. }\end{array}$ & 3,50 & 1,02 & $0,713 * *$ & CONG04 \\
\hline & The event and the main sponsor represent similar things. & 3,23 & 1,04 & $0,822 * *$ & CONG05 \\
\hline & It makes perfect sense for this brand to sponsor the event. & 3,63 & 1,00 & $0,796 * *$ & CONG06 \\
\hline \multirow{4}{*}{$\begin{array}{l}\text { Trust } \\
\text { (TRUS) } \\
\text { (Varki and } \\
\text { Ashley, 2011) }\end{array}$} & The sponsor's brand of the event is sincere. & 3,53 & 0,86 & $0,899 * *$ & TRUS01 \\
\hline & The sponsor's brand of the event is honest. & 3,51 & 0,84 & $0,922 * *$ & TRUS02 \\
\hline & The sponsor's brand of the event is reliable. & 3,71 & 0,83 & $0,878 * *$ & TRUS03 \\
\hline & Ads to this festival are compelling. & 3,91 & 0,83 & $0,725 * *$ & TRUS04 \\
\hline \multirow{4}{*}{$\begin{array}{l}\text { Consumption } \\
\text { (CONS) } \\
\text { (Schivinski, } \\
\text { Christodoulides } \\
\text {, and } \\
\text { Dabrowski, } \\
\text { 2016) }\end{array}$} & $\begin{array}{l}\text { I follow the social network pages of the sponsor of this } \\
\text { event. }\end{array}$ & 2,88 & 1,43 & $0,926 * *$ & CONS01 \\
\hline & $\begin{array}{l}\text { I see the images in the social network pages of the } \\
\text { sponsor of this event. }\end{array}$ & 2,99 & 1,38 & $0,916 * *$ & CONS02 \\
\hline & $\begin{array}{l}\text { I follow the comments on the social network pages of the } \\
\text { sponsor of this event. }\end{array}$ & 2,49 & 1,25 & $0,889 * *$ & CONS03 \\
\hline & $\begin{array}{l}\text { I make "like" in the sponsor brand publications on } \\
\text { Facebook / Instagram. }\end{array}$ & 2,69 & 1,36 & $0,920 * *$ & CONSO4 \\
\hline \multirow{3}{*}{$\begin{array}{l}\text { Contribution } \\
\text { (CONT) } \\
\text { (Schivinski, } \\
\text { Christodoulides } \\
\text {, and } \\
\text { Dabrowski, } \\
\text { 2016) }\end{array}$} & $\begin{array}{l}\text { I create publications about the festival sponsor brand on } \\
\text { Facebook / Instagram. }\end{array}$ & 2,00 & 1,15 & $0,916 * *$ & CONT01 \\
\hline & $\begin{array}{l}\text { Comment the publications made by sponsor brand or } \\
\text { other users on the Facebook / Instagram page }\end{array}$ & 1,98 & 1,03 & $0,896 * *$ & \multirow{2}{*}{$\begin{array}{l}\text { CONT02 } \\
\text { CONT03 }\end{array}$} \\
\hline & $\begin{array}{l}\text { I share sponsor brand publications on Facebook / } \\
\text { Instagram. }\end{array}$ & 2,15 & 1,18 & $0,892 * *$ & \\
\hline
\end{tabular}

$\lambda$ - Standardized Coefficients (Standardized Loadings); ** $\mathrm{p}<0,001$ 
Individuals answered through a questionnaire available online between November and December 2018, which 272 responses were obtained from individuals younger than 30 years of age, $73.2 \%$ are female and $78.3 \%$ of the individuals attended to music events in recent months. For the sample procedure, preliminary analyses were carried out. It was concluded that the constructs don't have problems of multicollinearity (VIF<5) (Maroco, 2014). Data analysis was performed through the PLS-SEM estimation which the first step in the analysis through PLS is the analysis to the measurement model. The study of the reliability and validity of the measurement model will provide confirmatory information about the reliability of each construct, its convergent validity and its discriminant validity. In order to perform this step, the "PLS algorithm" function was executed in the software SMART PLS 3.2.7. From the obtained data we only considered the values that had standardized coefficients $(\lambda)$ higher than 0.5 (table 1). From table 1 , it is possible to verify the factorial and convergent validity of the constructs (Hair et al., 2016; Vinzi, Chin, Henseler, \& Wang, 2010). Regarding the evaluation of the model of measures, the discriminant validity was confirmed through three criteria: criterion of Fornell and Larcker (1981) (table 3); cross-loadings evaluation criterion (table 4) and correlation ratio of Heterotrait-Monotrait (HTMT) of Henseler et al. (2015) (table 5).

Table 2. Results of the Measurement Model

\begin{tabular}{ccccc}
\hline Construct & $\begin{array}{c}\text { Cronbach } \boldsymbol{\alpha} \\
(>\mathbf{0 , 7})\end{array}$ & $\begin{array}{c}\text { Rho_A } \\
(>\mathbf{0 , 7})\end{array}$ & $\begin{array}{c}\text { CR } \\
(>\mathbf{0 , 7})\end{array}$ & $\begin{array}{c}\text { AVE } \\
(>\mathbf{0 , 5})\end{array}$ \\
\hline ATT & 0,915 & 0,920 & 0,937 & 0,747 \\
CONG & 0,841 & 0,846 & 0,884 & 0,561 \\
TRUS & 0,879 & 0,883 & 0,918 & 0,739 \\
CONS & 0,933 & 0,934 & 0,952 & 0,833 \\
CONT & 0,885 & 0,885 & 0,929 & 0,813 \\
\hline
\end{tabular}

AVE - Average Extracted Variance; CR - Composite Reliability;

Table 3. Discriminating Validity - Criterion of Fornell and Larcker (1981)

\begin{tabular}{lrrrrr}
\hline & TRUS & ATT & CONG & CONS & CONT \\
\hline Trust (TRUS) & 0,860 & & & & \\
Attitude towards advertising (ATT) & 0,429 & 0,864 & & & \\
Sponsorship Congruity (CONG) & 0,581 & 0,518 & 0,749 & & \\
Consumption (CONS) & 0,452 & 0,509 & 0,496 & 0,913 & \\
Contribution (CONT) & 0,303 & 0,385 & 0,365 & 0,710 & 0,902 \\
\hline
\end{tabular}

Table 4. Ratio of Heterotrait-Monotrait Correlations (HTMT)

\begin{tabular}{lccccc}
\hline & TRUS & ATT & CONG & CONS & CONT \\
\hline Trust (TRUS) & & & & & \\
Attitude towards advertising (ATT) & 0,476 & & & & \\
Sponsorship Congruity (CONG) & 0,671 & 0,586 & & \\
Consumption (CONS) & 0,501 & 0,548 & 0,559 & \\
Contribution (CONT) & 0,341 & 0,426 & 0,424 & 0,778 \\
\hline
\end{tabular}


Table 5. Discriminant Validity

\begin{tabular}{lrrrrr}
\hline & \multicolumn{1}{c}{ TRUS } & \multicolumn{1}{l}{ ATT } & \multicolumn{1}{l}{ CONG } & CONS & CONT \\
\hline ATT01 & 0,359 & 0,835 & 0,435 & 0,428 & 0,308 \\
ATT02 & 0,309 & 0,822 & 0,338 & 0,373 & 0,296 \\
ATT03 & 0,365 & 0,869 & 0,471 & 0,493 & 0,376 \\
ATT04 & 0,401 & 0,919 & 0,487 & 0,447 & 0,341 \\
ATT05 & 0,412 & 0,874 & 0,489 & 0,446 & 0,336 \\
CONG01 & 0,390 & 0,472 & 0,685 & 0,407 & 0,396 \\
CONG02 & 0,341 & 0,422 & 0,653 & 0,433 & 0,390 \\
CONG03 & 0,440 & 0,368 & 0,806 & 0,325 & 0,163 \\
CONG04 & 0,426 & 0,314 & 0,713 & 0,284 & 0,192 \\
CONG05 & 0,443 & 0,353 & 0,822 & 0,391 & 0,264 \\
CONG06 & 0,548 & 0,394 & 0,796 & 0,377 & 0,236 \\
TRUS01 & 0,899 & 0,360 & 0,552 & 0,379 & 0,279 \\
TRUS02 & 0,922 & 0,395 & 0,524 & 0,410 & 0,290 \\
TRUS03 & 0,878 & 0,331 & 0,461 & 0,379 & 0,222 \\
TRUS04 & 0,725 & 0,385 & 0,452 & 0,383 & 0,243 \\
CON501 & 0,444 & 0,466 & 0,453 & 0,926 & 0,605 \\
CON502 & 0,426 & 0,493 & 0,458 & 0,916 & 0,584 \\
CON503 & 0,369 & 0,433 & 0,450 & 0,889 & 0,694 \\
CON504 & 0,413 & 0,467 & 0,449 & 0,920 & 0,702 \\
CONT01 & 0,250 & 0,353 & 0,333 & 0,627 & 0,916 \\
CONT02 & 0,245 & 0,312 & 0,296 & 0,627 & 0,896 \\
CONT03 & 0,321 & 0,375 & 0,355 & 0,665 & 0,892 \\
\hline
\end{tabular}

The second step through the PLS-SEM methodology is the analysis to the structural model that aims to test the hypotheses under study through the analysis of path coefficients and the analysis of their significance (Avkiran \& Ringle, 2018; Hair et al., 2016; Henseler et al., 2015; Vinzi et al., 2010). For this purpose, we used the bootstrap resampling technique with 5000 sub-samples to be able to have stability in the obtained results. The accomplishment of this analysis allowed to obtain the results that will serve to test the hypotheses under study through the analysis of the standardized path coefficients (Std $\beta$ ). In addition to this analysis, the significance of each relation was verified through Student's t-value, p-value from which the results presented in the figure 3 which are summarized in table 6.

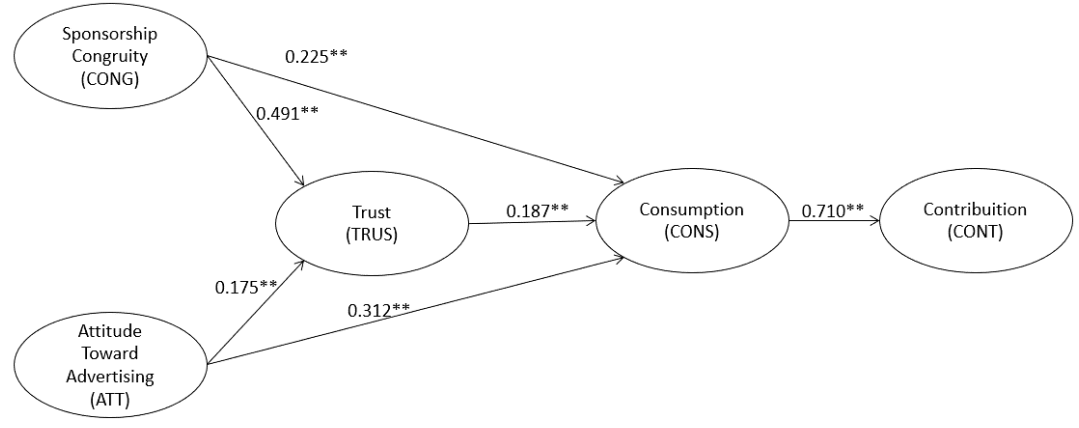

Figure 3. Structural Model 
Table 6. Summary of Hypothesis Test Results

\begin{tabular}{ccccc}
\hline Hypothesis & $\begin{array}{c}\text { Structural } \\
\text { Relationship }\end{array}$ & Std $\boldsymbol{\beta}$ & t-Value & Results \\
\hline H1 & CONG $\rightarrow$ TRUS & $0.491 * * *$ & 9.118 & Supported \\
H2 & CONG $\rightarrow$ CONS & $0.225 * * *$ & 3.756 & Supported \\
H3 & ATT $\rightarrow$ TRUS & $0.175 * *$ & 2.964 & Supported \\
H4 & ATT $\rightarrow$ CONS & $0.312^{* * *}$ & 5.485 & Supported \\
H5 & TRUS $\rightarrow$ CONS & $0.187 * * *$ & 3.466 & Supported \\
H6 & CONS $\rightarrow$ CONT & $0.710^{* * *}$ & 24.483 & Supported \\
\hline \multicolumn{5}{c}{$*$ p $<0.05 ; * * \mathrm{p}<0.01 ; * * * \mathrm{p}<0.001$} \\
\end{tabular}

\section{DISCUSSION}

Brands have sought to increase exposure to their potential customers in several ways. Bringing audiences to the digital environments where brands communicate has been a present challenge. Therefore, this paper aims to explain the engagement of individuals with brands in the social media environment.

Engagement in social media is, according to Schivinski et al. (2016) based in Mutinga's COBRA framework (Muntinga, 2011), composed of three dimensions: consumption, contribution and creation. However, only consumption and contribution (base in authors such as Tsai \& Men, 2013) were analysed in this study.

This study developed a research model that identified trust, attitude toward "new" advertising, and congruence between the sponsoring brand and the event as influencing factors in social media engagement. Thus, we tested the hypotheses of investigation, which were based on the analysis to individuals less than 30 years old. From the hypothesis test, the model explains that trust in the sponsoring brand of an event is explained $\left(\mathrm{R}^{2}=0.360\right)$ by the congruence between the sponsoring brand and the event $\left(\beta_{\text {CONG } \rightarrow \text { TRUS }}=0.491\right.$; $t=9.118 ; p<0.001)$ and by the attitude of individuals to creative brand advertising $\left(\beta_{\mathrm{ATT} \rightarrow \mathrm{TRUS}}=0.175\right.$ $t=2.964 ; p<0.01$.

In the engagement in social networks, consumption is considered an initial level of engagement that, by the results obtained is influenced $\left(\mathrm{R}^{2}=0,355\right)$ by congruence $\left(\beta_{\mathrm{CONG} \rightarrow \mathrm{CONS}}=0.225 ; t=3.756 ; p<0.001\right)$ by the attitude of individuals to advertising $\left(\beta_{\mathrm{ATT} \rightarrow \mathrm{CONS}}=0.312 ; t=5.485 ; p<0.001\right)$ and by trust $\left(\beta_{\text {TRUS } \rightarrow \text { CONS }}=0.187 ; t=3.466 ; p<0.001\right)$.

It is thus explained that congruence and attitude towards advertising are important to create positive feelings and trust (Sirgy et al., 2008; Varki \& Ashley, 2011) and the engagement with the brands is superior whenever the sensations are positive, leaving the brand reinforced (Woisetschläger \& Michaelis, 2012).

At a higher level of engagement of individuals in social networks, the contribution is explained $\left(\mathrm{R}^{2}=0,504\right)$ by the individuals' own consumption of content $\left(\mathrm{B}_{\mathrm{CONS} \rightarrow \mathrm{CON}}=0.710 ; \mathrm{t}=24.483 ; \mathrm{p}<0.001\right)$.

\section{CONCLUSION}

The results showed that the dimensions of engagement in social networks are explained by the variables included in the model tested. In this way, the work presents theoretical and practical contributions.

The theoretical advances focus mainly on the presented model that explains the involvement through the variables analysed. Thus, the congruence between the sponsored brand and the event is proving to be of utmost importance, as is the attitude towards advertising and also trust. Thus, at the practical level, this work has relevance for the management of brands since it reports that the brands should look with special attention to the events before they sponsor them. Greater engagement with brands increases the value of brands and, accordingly, congruence is a key factor in social networks. Thus, the sponsorship should follow a strategic analysis in order to enhance the engagement of the public with the brands. 
Although the conclusions are relevant, this study had limitations because the analyzes are based on a sample of young individuals (under 30 years of age) and mostly female. These limitations suggest new studies with more diversified samples.

\section{REFERENCES}

Avkiran, N. K. et al, 2018. Partial Least Squares Structural Equation Modeling: Recent Advances in Banking and Finance: Springer International Publishing.

Baack, D. W. et al, 2016. Advertising to businesses: Does creativity matter? Industrial Marketing Management, Vol. 55, pp. $169-177$

Burmann, C. et al, 2009. Towards an identity-based brand equity model. Journal of Business Research, Vol. 62, No. 3, pp. 390-397.

Chebli, L. et al, 2014. The Impact of the Effectiveness of Sponsorship on Image and Memorizing: Role of Congruence and Relational Proximity. Procedia - Social and Behavioral Sciences, Vol. 109, pp. 913-924.

Cheung, C. M. K. et al, 2011. Online social networks: Why do students use facebook? Computers in Human Behavior, Vol. 27, No. 4, pp. 1337-1343.

Crompton, J. L. et al, 1997. Motives of visitors attending festival events. Annals of Tourism Research, Vol. 24, No. 2, pp. 425-439.

de Waal Malefyt, T., 2015. Relationship advertising: How advertising can enhance social bonds. Journal of Business Research, Vol. 68, No.12, pp. 2494-2502

Fornell, C. et al, 1981. Evaluating structural equation models with unobservable variables and measurement error. Journal of Marketing Research, Vol. 18, No. 1, pp. 39-50.

Gursoy, D. et al, 2004. Perceived impacts of festivals and special events by organizers: an extension and validation. Tourism Management, Vol. 25, No. 2, pp. 171-181.

Hair, J. F. et al, 2016. A Primer on Partial Least Squares Structural Equation Modeling (PLS-SEM): SAGE Publications.

Henseler, J. et al, 2015. A new criterion for assessing discriminant validity in variance-based structural equation modeling. Journal of the Academy of Marketing Science, Vol. 43, No. 1, pp. 115-135.

Hudson, S. et al, 2016. The influence of social media interactions on consumer-brand relationships: A three-country study of brand perceptions and marketing behaviors. International Journal of Research in Marketing, Vol. 33, No.1, pp. 27-41.

Hudson, S. et al, 2015. The effects of social media on emotions, brand relationship quality, and word of mouth: An empirical study of music festival attendees. Tourism Management, Vol. 47, pp. 68-76.

Koo, J. et al, 2018. Sponsor-event congruence effects: The moderating role of sport involvement and mediating role of sponsor attitudes. Sport Management Review.

Lau, G. T. et al, 1999. Consumers' Trust in a Brand and the Link to Brand Loyalty. Journal of Market-Focused Management, Vol. 4, No. 4, pp. 341-370.

Maroco, J. (2014). Análise Estatística com o SPSS. $\sigma^{a}$ Edição. Pêro Pinheiro: Report Number.

Muntinga, D. et al, 2011. Introducing COBRAs. International Journal of Advertising, Vol. 30, No.1, pp. 13-46.

Pochun, T. et al, 2018. Advertising effects? An elemental experiment. Australasian Marketing Journal (AMJ), Vol. 26, No. 4, pp. 338-349.

Rowley, J. et al, 2008. The impact of brand sponsorship of music festivals. Marketing Intelligence \& Planning, Vol. 26, No. 7, pp. 781-792.

Shin, H. et al, 2018. The congruity effects of commercial brand sponsorship in a regional event. Tourism Management, Vol. 67, pp. 168-179.

Sirgy, J. et al, 2008. Effect of self-congruity with sponsorship on brand loyalty. Journal of Business Research, Vol. 61, No. 10, pp. 1091-1097.

Tsai, W.H. et al, 2013. Motivations and Antecedents of Consumer Engagement With Brand Pages on Social Networking Sites. Journal of Interactive Advertising, Vol. 13, No.2, pp. 76-87.

Xiang, Z. et al, 2010. Role of Social Media in Online Travel Information Search. Tourism Management, Vol. 31, No. 2, pp. $179-188$.

Varki, S. et al, 2011. The Differential Effect of Ad Novelty and Message Usefulness on Brand Judgments AU - Sheinin, Daniel A. Journal of Advertising, Vol. 40, No. 3, pp. 5-18.

Woisetschläger, D. M. et al, 2012. Sponsorship congruence and brand image: A pre-post event analysis. European Journal of Marketing, Vol. 46, No.3/4, pp. 509-523. 